\title{
Aluminium in Acid Soils: Chemistry, Toxicity and Impact on Maize Plants
}

\author{
Dragana Krstic ${ }^{1}$, Ivica Djalovic ${ }^{2}$, \\ Dragoslav Nikezic ${ }^{1}$ and Dragana Bjelic ${ }^{3}$ \\ ${ }^{1}$ University of Kragujevac, Faculty of Science \\ Institute of Field and Vegetable Crops \\ ${ }^{3}$ University of Kragujevac, Faculty of Agronomy
}

Serbia

\section{Introduction}

Soil acidity is a limiting factor affecting the growth and yield of many crops all over the world. The basic problems concerning chemical properties of more acid soils are, besides acidity itself, the presence of toxic compounds and elements, such as soluble forms of $\mathrm{Al}, \mathrm{Fe}$ and $\mathrm{Mn}$, nitrites and various toxic organic acids. Aluminium ( $\mathrm{Al}$ ) toxicity is one of the major constraints on crop productivity on acid soils, which occur on up to $40 \%$ of the arable lands of the world. Al is the third most abundant element in the earth's crust and is toxic to plants when solubilised into soil solution at acidic $\mathrm{pH}$ values (Kochian, 1995). A total of 3950 million hectares of land is classed as having acidic soil, of which $15 \%$ is used for planting of annual and perennial crops (von Uexküll \& Mutert, 1995).

Northern belt of acid soils occurring in the humid northern temperate zone is comprised of predominantly organic acid soils and supports coniferous forests. A southern belt of mineral acid soils occurs in the humid tropics. Currently approximately $12 \%$ of land in crop production is acidic (Uexküll \& Mutert, 1995), however, the nutriextent of acid soil is increasing world-wide. Mineral acid soils result from parent materials that are acidic and naturally low in the basic cations $(\mathrm{Ca}, \mathrm{Mg}, \mathrm{K}$ and $\mathrm{Na}$ ), or because these elements are leached from the soil, reducing $\mathrm{pH}$ and the buffering capacity of the soil. As soil $\mathrm{pH}$ decreases, aluminum ( $\mathrm{Al})$ is solubilized and the proportion of phytotoxic aluminium ions increases in the soil solution. In most mineral soils there is sufficient $\mathrm{Al}$ present to buffer the soil to around $\mathrm{pH}$ 4. Organic acid soils, consisting of large amounts of humic acids and partially decomposed plant matter, typically have little $\mathrm{Al}$ buffering and the $\mathrm{pH}$ of these soils can fall rather below $\mathrm{pH} 4$ (Kidd, 2001).

A number of factors contribute to acid soil toxicity transdepending on soil composition. In acid soils with a high mineral content, the primary factor limiting plant growth is $\mathrm{Al}$ toxicity. The $\mathrm{Al}$ released from soil minerals under acid conditions occurs as $\mathrm{Al}(\mathrm{OH})_{2}{ }^{+}$, $\mathrm{Al}(\mathrm{OH})$ and $\mathrm{Al}\left(\mathrm{H}_{2} \mathrm{O}\right)^{3+}$, the latter commonly referred to as $\mathrm{Al}$ (Kinraide, 1991). For most agriculturally important plants, $\mathrm{Al}$ ions rapidly inhibit root growth at micromolar concentrations. 
The primary target of $\mathrm{Al}$ toxicity is the root apex. Aluminium affects a host of different cellular functions, frustrating attempts to identify the principal effect(s) of Al toxicity. Exposure to $\mathrm{Al}$ causes stunting of the primary root and inhibition of lateral root formation. Affected root tips are stubby due to inhibition of cell elongation and cell division. The resulting restricted root system is impaired in nutrient and water uptake, making the plant more susceptible to drought stress. Plants sensitive to $\mathrm{Al}$ toxicity have greatly reduced yield and crop quality (Samac \& Tesfaye, 2003; Jovanovic et al., 2006; 2007).

The influence of physical-chemical characteristics of soil on distribution of some elements and availability for plants in vertisols of Serbia are confirmed (Krstic et al., 2004; Krstic et al., 2007; Dugalic et al., 2010; Jelic et al., 2010; Milivojevic et al., 2011) Aim of this study was testing of soil $\mathrm{pH}$, exchangeable acidity and mobile aluminium (Al) status in profiles of pseudogley soils of Čačak-Kraljevo basin.

\subsection{Aluminium chemistry in the soil}

Aluminium, bound as oxides and complex aluminosilicates, ranks third in abundance among the elements in the Earth's crust. Despite much research since Hartwell and Pember first postulated, nearly 90 years ago, that soluble aluminium is a major inhibitor of plant growth in acid soils, the mechanism of aluminium phytotoxicity is not yet fully understood. Aluminium can inhibit root growth at the organ, tissue, and cellular levels at micromolar concentrations (Ciamporová, 2002). Acid soils, present mostly in humid tropical and subtropical areas of the world, are characterized by having excess $\mathrm{H}^{+}, \mathrm{Mn}^{2+}$, and $\mathrm{Al}_{3}{ }^{+}$, with deficiencies of $\mathrm{Ca}^{2+}, \mathrm{Mg}^{2+}$, and $\mathrm{PO}_{4}{ }^{3-}$. Additionally, sulfur dioxide and other air pollutants cause acid soil stress in areas other than the tropics (Foy, 1984). In acidic soils, hydroxyl-rich aluminium compounds solubilize to an extent in the soil solution. Forty percent of the arable land globally is acidic because of solubilization of the abundantly present aluminium, greatly limiting crop productivity.

Aluminium chemistry is quite complex. It has a high ionic charge and a small crystalline radius, which gives it a level of reactivity that is unmatched by other soluble metals. When the $\mathrm{pH}$ of a solution is raised above 4.0, $\mathrm{A}^{3+}$ forms the mononuclear species $\mathrm{AlOH}_{2}{ }^{+}$, $\mathrm{Al}(\mathrm{OH})_{2}{ }^{+}, \mathrm{Al}(\mathrm{OH})_{3}$, and $\mathrm{Al}(\mathrm{OH})_{4}{ }^{+}$, and soluble complexes with inorganic ligands such as sulfate and fluoride, $\mathrm{A}_{1} \mathrm{~F}_{2}{ }^{+}, \mathrm{AlF}_{3}{ }^{+}, \mathrm{Al}(\mathrm{SO})_{4}{ }^{+}$, and also with many organic compounds. Larger polynuclear hydroxyl aluminium species also form as metastable intermediates during $\mathrm{AI}(\mathrm{OH})_{3}$ precipitation. The mononuclear $\mathrm{A}^{3+}$ species seems to be most toxic at low $\mathrm{pH}$, at which it exists as an octahedral hexahydrate. With increasing $\mathrm{pH}, \mathrm{Al}\left(\mathrm{H}_{2} 0\right)^{3+}{ }_{6}$ undergoes repeated deprotonations to form insoluble $\mathrm{Al}(\mathrm{OH})_{3}$ at $\mathrm{pH}$ 7.0. At cytosolic $\mathrm{pH}, 7.4$ aluminate ion, $\mathrm{Al}(\mathrm{OH})_{4^{-}}$, is formed. In near neutral solutions, polynuclear forms of aluminium, which contain more than one aluminium atom, occurs. One of the most important polymer triskaidekaaluminium, $\mathrm{AlO}_{4} \mathrm{Al}_{12}(\mathrm{OH})_{24}\left(\mathrm{H}_{2} \mathrm{O}\right)_{127^{+}}$refered as $\mathrm{Al}_{13}$ (Parker \& Bertsch, 1992), seems to be the most toxic $\mathrm{Al}$ specie.

\section{Material and methods}

\subsection{General characteristics of the Čačak-Kraljevo Basin}

Čačak-Kraljevo basin is part of western Serbia (Morava river area). It is narrow belt longitude approximately $70 \mathrm{~km}$ in NW-SE direction and width from 5 to $18 \mathrm{~km}$. Kablar, 
Ovčar, Troglav, Stolovi, Goč, Suvobor, Vujno and Kotlenik mountains are border toward SW and NE directions. Pseudogley soils of this area (approximately 32.000 hectares situated mainly in latitudes between 180 and $200 \mathrm{~m}$ above sea level) have been developed on diluvial-holocene terrace of Western Morava and its tributaries. Climate of this area is moderate continental characterizing mean annual air-temperature $11.2{ }^{\circ} \mathrm{C}$ (winter $1.4^{\circ} \mathrm{C}$, summer $20.5^{\circ} \mathrm{C}$ ) and precipitation $715.8 \mathrm{~mm}$ (Kraljevo Weather Bureau; means 1961-1990).

\subsection{Sampling and chemical analysis}

Total 102 soil profiles were opened during 2008 at certain sites of the Čačak-Kraljevo basin. The tests encompassed 54 field, 28 meadow, and 20 forest profiles. From the opened profiles, samples of soil in the disturbed state were taken from the humus and Eg horizons (102 profiles); then from the $B_{1} \operatorname{tg}$ horizon of 39 fields, 24 meadows and 15 forest profiles (total 78) and from the $B_{2}$ tg horizon of 14 fields, 11 meadows, and 4 forest profiles (total 29). Laboratory determination of exchangeable acidity was conducted in a suspension of soil with a $1.0 \mathrm{M} \mathrm{KCl}$ solution ( $\mathrm{pH}$ 6.0) using a potentiometer with a glass electrode, as well as by Sokolov's method, where the content of $\mathrm{Al}$ ions in the extract is determined in addition to total exchangeable acidity $\left(\mathrm{H}^{+}+\mathrm{Al}^{3+}\right.$ ions) (Jakovljevic et al., 1995).

\section{Results and discussion}

This mean $\mathrm{pH}(1 \mathrm{M} \mathrm{KCl})$ of tested soil profiles were 4.28, 3.90 and 3.80, for Ah, Eg and $\mathrm{B}_{1}$ tg horizons, respectively. Also, soil $\mathrm{pH}$ of forest profiles was lower in comparison with meadows and arable lands (means: 4.06, 3.97 and 3.85, for arable lands, meadows and forest, respectively). Soil acidification is especially intensive in deeper horizons because $27 \%$ (Ah), $77 \%(\mathrm{Eg})$ and $87 \%\left(\mathrm{~B}_{1} \mathrm{tg}\right)$ soil profiles have $\mathrm{pH}$ lower than 4.0 (Table 1$)$.

\begin{tabular}{|c|c|c|c|c|c|c|c|c|}
\hline \multicolumn{9}{|c|}{ Distribution of $\mathrm{pH}(1 \mathrm{M} \mathrm{KCl})$ in soil profiles $(a=$ arable land; $\mathrm{m}=$ meadow; $\mathrm{f}=$ forest) } \\
\hline \multirow{3}{*}{ Horizons } & \multirow{3}{*}{$\mathrm{n}$} & \multicolumn{5}{|c|}{$\mathrm{pH}(1 \mathrm{M} \mathrm{KCl})$} & \multicolumn{2}{|c|}{$\mathrm{pH}$ values } \\
\hline & & $<4.0$ & $4.1-4.5$ & $4.6-5.1$ & $>5.1$ & Sum & \multirow{2}{*}{ Mean } & \multirow{2}{*}{ Range } \\
\hline & & \multicolumn{5}{|c|}{$\mathrm{pH}(1 \mathrm{M} \mathrm{KCl})$ in $\%$ of total $(\mathrm{n})$ tested profiles } & & \\
\hline Ah (a) & 54 & 18.5 & 57.5 & 22.2 & 1.8 & 100 & 4.33 & $3.7-5.2$ \\
\hline Ah (m) & 24 & 20.8 & 75.0 & 4.2 & 0.0 & 100 & 4.25 & $3.9-4.8$ \\
\hline $\mathrm{Ah}(\mathrm{f})$ & 20 & 55.0 & 30.0 & 5.0 & 10.0 & 100 & 4.18 & $3.6-5.3$ \\
\hline Ah (total) & 98 & 26.5 & 56.1 & 14.3 & 3.1 & 100 & 4.28 & $3.6-5.3$ \\
\hline $\mathrm{Eg}(\mathrm{a})$ & 54 & 64.8 & 27.8 & 7.4 & 0.0 & 100 & 3.99 & $3.6-5.1$ \\
\hline $\mathrm{Eg}(\mathrm{m})$ & 24 & 91.7 & 8.3 & 0.0 & 0.0 & 100 & 3.89 & $3.6-4.5$ \\
\hline $\operatorname{Eg}(f)$ & 20 & 90.0 & 10.0 & 0.0 & 0.0 & 100 & 3.69 & $3.4-4.1$ \\
\hline $\mathrm{Eg}$ (total) & 98 & 76.5 & 19.4 & 4.1 & 0.0 & 100 & 3.90 & $3.4-5.1$ \\
\hline $\mathrm{B}_{1} \operatorname{tg}(\mathrm{a})$ & 39 & 76.9 & 20.5 & 2.6 & 0.0 & 100 & 3.86 & $3.5-4.6$ \\
\hline $\mathrm{B}_{1} \operatorname{tg}(\mathrm{m})$ & 20 & 95.0 & 5.0 & 0.0 & 0.0 & 100 & 3.78 & $3.6-4.4$ \\
\hline$B_{1} \operatorname{tg}(\mathrm{f})$ & 17 & 100.0 & 0.0 & 0.0 & 0.0 & 100 & 3.69 & $3.5-4.0$ \\
\hline $\mathrm{B}_{1}$ tg (total) & 76 & 86.9 & 11.8 & 1.3 & 0.0 & 100 & 3.80 & $3.5-4.6$ \\
\hline $\mathrm{B}_{2} \operatorname{tg}$ (total) & 31 & 90.2 & 6.6 & 3.2 & 0.0 & 100 & 3.83 & $3.6-4.8$ \\
\hline
\end{tabular}

Table 1. Distribution of $\mathrm{pH}(1 \mathrm{M} \mathrm{KCl})$ in soil profiles 
Mean total exchangeable acidity (TEA) of tested soil profiles were 1.55, 2.33 and 3.40 meq $100 \mathrm{~g}-1$, for $\mathrm{Ah}, \mathrm{Eg}$ and $\mathrm{B}_{1} \operatorname{tg}$ horizons, respectively. However, it is considerably higher in forest soils (mean 3.39 meq 100g-1) than in arable soils and meadows (means 1.96 and 1.93, respectively).

The deeper horizons (Eg and $\mathrm{B}_{1} \mathrm{tg}$ ) of meadows and forest soil profiles have especially high TEA values. Especially high frequencies of the high TEA values (over 3.0 meq 100 $\mathrm{g}^{-1}$ ) were found in forest soil profiles (Table 2).

\begin{tabular}{|c|c|c|c|c|c|c|c|c|}
\hline \multirow{3}{*}{ Horizons } & \multirow{3}{*}{$\mathrm{n}$} & \multicolumn{5}{|c|}{ TEA (meq 100g-1) } & \multicolumn{2}{|c|}{ TRA (meq 100g-1) } \\
\hline & & $<1.0$ & $1-2$ & $2-3$ & $>3.0$ & Sum & \multirow{2}{*}{ Mean } & \multirow{2}{*}{ Range } \\
\hline & & \multicolumn{5}{|c|}{ TEA in $\%$ of total $(n)$ tested profiles } & & \\
\hline $\operatorname{Ah}(\mathrm{a})$ & 53 & 86.8 & 13.2 & 0.0 & 0.0 & 100 & 0.96 & $0.07-1.84$ \\
\hline $\mathrm{Ah}(\mathrm{m})$ & 27 & 85.2 & 14.8 & 0.0 & 0.0 & 100 & 0.90 & $0.22-1.58$ \\
\hline $\operatorname{Ah}(\mathrm{f})$ & 20 & 55.0 & 20.0 & 5.0 & 20.0 & 100 & 2.79 & $0.09-5.49$ \\
\hline Ah (total) & 100 & 80.0 & 15.0 & 1.0 & 4.0 & 100 & 1.55 & $0.07-5.49$ \\
\hline $\mathrm{Eg}(\mathrm{a})$ & 53 & 35.8 & 37.8 & 22.6 & 3.8 & 100 & 1.80 & $0.16-3.44$ \\
\hline $\mathrm{Eg}(\mathrm{m})$ & 27 & 18.5 & 63.0 & 11.1 & 7.4 & 100 & 1.85 & $0.37-3.33$ \\
\hline $\operatorname{Eg}(f)$ & 20 & 10.0 & 20.0 & 30.0 & 40.0 & 100 & 3.34 & $0.58-6.09$ \\
\hline Eg (total) & 100 & 26.0 & 41.0 & 21.0 & 12.0 & 100 & 2.33 & $0.16-6.09$ \\
\hline $\mathrm{B}_{1} \operatorname{tg}(\mathrm{a})$ & 37 & 24.3 & 18.9 & 24.3 & 32.5 & 100 & 3.12 & $0.23-6.01$ \\
\hline $\mathrm{B}_{1} \operatorname{tg}(\mathrm{m})$ & 23 & 8.7 & 21.7 & 39.2 & 30.4 & 100 & 3.05 & $0.60-5.49$ \\
\hline$B_{1} \operatorname{tg}(f)$ & 14 & 0.0 & 21.4 & 28.6 & 50.0 & 100 & 4.03 & $1.36-6.69$ \\
\hline $\mathrm{B}_{1}$ tg (total) & 74 & 14.8 & 20.3 & 29.6 & 35.3 & 100 & 3.40 & $0.23-6.69$ \\
\hline $\mathrm{B}_{2} \operatorname{tg}$ (total) & 29 & 14.8 & 27.6 & 36.5 & 21.1 & 100 & 2.62 & $0.70-5.54$ \\
\hline
\end{tabular}

Table 2. Distribution of total exchangeable acidity (sum of $\mathrm{H}^{+}$and $\mathrm{Al}^{3+}$ ) in soil profiles

Mean mobile Al contents of tested soil profiles were 11.02, 19.58 and $28.33 \mathrm{mg} \mathrm{Al} 100 \mathrm{~g}^{-1}$, for $\mathrm{Ah}, \mathrm{Eg}$ and $\mathrm{B}_{1} \operatorname{tg}$ horizons, respectively. Soil $\mathrm{pH}$ and TEA in forest soils are considerably higher (mean 26.08 meq $\mathrm{Al} 100 \mathrm{~g}^{-1}$ ) than in arable soils and meadows (means 16.85 and 16.00 $\mathrm{Al} 100 \mathrm{~g}^{-1}$, respectively). The Eg and $\mathrm{B}_{1}$ tg horizons of forest soil profiles have especially high mobile $\mathrm{Al}$ contents (means 28.50 and $32.95 \mathrm{mg} \mathrm{Al} 100 \mathrm{~g}^{-1}$, respectively). Frequency of high levels of mobile $\mathrm{Al}$ is especially high in forest soils because 35\% (Ah), 85.0\% (Eg) and 93.3\%

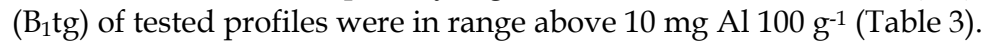

Increased TEA is characteristics of soils in which acidification processes are rather for advanced, the reaction of their soil solutions being fairly acidic, which $\mathrm{pH}$ values are lower than 5.0. This is typical for pseudogley which is the most widely disseminated type of soil in the Čačak-Kraljevo basin. Due to the fact that $\mathrm{Al}$ ions in an increased concentration are 
much more dangerous for plants than $\mathrm{H}^{+}$ions in the same concentration at the same value of TEA, plants increasingly suffer if a higher share of $\mathrm{Al}$ ions is present in it. Already at the content of $6-10 \mathrm{mg} 100 \mathrm{~g}^{-1}$ of readily mobile $\mathrm{Al}$ in the soil, plant growth is retarded to a greater or lesser extent depending on the species (Rengel, 2004). High TEA, created predominantly by $\mathrm{Al}$ ions, is among the most important causes of the low productive capacity of pseudoglay in the indicated basin where, despite of fertilizer use and application of different agrotechnical measures, average yields of cultivated plants are low and vary fairly greatly depending on weather conditions of the year.

\begin{tabular}{|c|c|c|c|c|c|c|c|c|}
\hline \multicolumn{9}{|c|}{ Mobile aluminum contents in soil profiles $(\mathrm{a}=$ arable land; $\mathrm{m}=$ meadow; $\mathrm{f}=$ forest $)$} \\
\hline \multirow{3}{*}{ Horizons } & \multirow{3}{*}{$\mathrm{n}$} & \multicolumn{5}{|c|}{ Mobile aluminum (mg Al $100 \mathrm{~g}^{-1}$ ) } & \multicolumn{2}{|c|}{$\operatorname{mg~Al~} 100 g^{-1}$} \\
\hline & & $<3.0$ & $3.1-6.0$ & $6.1-10$ & $>10$ & Sum & \multirow[t]{2}{*}{ Mean } & \multirow[t]{2}{*}{ Range } \\
\hline & & \multicolumn{5}{|c|}{ Mobile aluminum in $\%$ of total } & & \\
\hline Ah (a) & 54 & 63.0 & 18.5 & 11.1 & 7.4 & 100 & 8.15 & $0.2-16.1$ \\
\hline Ah $(\mathrm{m})$ & 28 & 64.4 & 17.8 & 7.1 & 10.7 & 100 & 8.10 & $1.0-15.2$ \\
\hline $\operatorname{Ah}(\mathrm{f})$ & 20 & 40.0 & 10.0 & 15.0 & 35.0 & 100 & 16.80 & $0.4-33.2$ \\
\hline Ah (total) & 102 & 58.8 & 16.3 & 10.8 & 14.1 & 100 & 11.02 & $0.2-33.2$ \\
\hline Eg (a) & 54 & 20.4 & 13.0 & 12.9 & 53.7 & 100 & 15.40 & $0.5-30.3$ \\
\hline $\operatorname{Eg}(\mathrm{m})$ & 28 & 10.7 & 7.1 & 21.4 & 60.8 & 100 & 14.85 & $0.3-29.4$ \\
\hline $\operatorname{Eg}(f)$ & 20 & 0.0 & 15.0 & 0.0 & 85.0 & 100 & 28.50 & $3.5-53.5$ \\
\hline Eg (total) & 102 & 13.7 & 11.8 & 12.8 & 61.7 & 100 & 19.58 & $0.3-53.5$ \\
\hline $\mathrm{B}_{1} \operatorname{tg}(\mathrm{a})$ & 39 & 12.8 & 12.8 & 7.7 & 66.7 & 100 & 27.00 & $1.0-53.0$ \\
\hline $\mathrm{B}_{1} \operatorname{tg}(\mathrm{m})$ & 24 & 0.0 & 8.3 & 12.5 & 79.2 & 100 & 25.05 & $3.2-46.9$ \\
\hline$B_{1} \operatorname{tg}(f)$ & 15 & 0.0 & 0.0 & 6.7 & 93.3 & 100 & 32.95 & $7.9-58.0$ \\
\hline $\mathrm{B}_{1}$ tg (total) & 78 & 6.4 & 9.0 & 8.9 & 75.7 & 100 & 28.33 & $1.0-58.0$ \\
\hline $\mathrm{B}_{2} \operatorname{tg}$ (total) & 29 & 0.0 & 14.2 & 13.5 & 72.3 & 100 & 20.50 & $3.6-37.4$ \\
\hline
\end{tabular}

Table 3. Distribution of mobile aluminium in soil profiles

\subsection{Aluminium Influence on maize plants}

Al ions translocate very slowly to the upper parts of plants (Ma et al., 1997). Most plants contain no more than $0.2 \mathrm{mg} \mathrm{Al} \mathrm{g}^{-1}$ dry mass. However, some plants, known as $\mathrm{Al}$ accumulators, may contain over 10 times more $\mathrm{Al}$ without any injury. Tea plants are typical $\mathrm{Al}$ accumulators: the $\mathrm{Al}$ content in these plants can reach as high as $30 \mathrm{mg} \mathrm{g}^{-1}$ dry mass in old leaves (Matsumoto et al., 1976). Approximately 400 species of terrestrial plants, belonging to 45 families, have so far been identified as hyperaccumulators of various toxic metals (Baker et al., 2000). 
The main aluminum toxicity symptom is inhibition of root elongation with simultaneous induction of $\beta-1,3$-glucan (callose) synthesis, which is apparent alter even a short exposure time. Aluminium causes extensive root injury, leading to poor ion and water uptake (Barcelo \& Poschenrieder, 2002). One of hypothesis is that the sequence of toxicity starts with perception of aluminum by the root cap cells, followed by signal transduction and a physiological response within the root meristem. However, recent work has ruled out a role of the root cap and emphasizes that the root meristem is the sensitive site. Root tips have been found to be the primary site of aluminum injury, and the distal part of the transition zone has been identified as the target site in maize (Zea mays) (Sivaguru \& Horst, 1998). Root cells division results in root elongation. Aluminum is known to induce a decrease in mitotic activity in many plants, and the aluminum-induced reduction in the number of proliferating cells is accompanied by the shortening of the region of cell division in maize (Panda, 2007).

Blancaflor et al. (1998) have studied Al-induced effects on microtubules and actin microfilaments in elongating cells of maize root apices, and related the Al-induced growth inhibition to stabilization of microtubules in the central elongation zone. With respect to growth determinants (auxin, gibberelic acid and ethylene), Al apparently interacts directly and/or indirectly with the factors that influence organization of the cytoskeleton, such as cytosolic levels of $\mathrm{Ca}^{2+}$ (Jones et al., 2006), $\mathrm{Mg}^{2+}$ and calmodulin (Grabski et al., 1998), cellsurface electrical potential (Takabatake \& Shimmen, 1997), callose formation (Horst et al., 1997) and lipid composition of the plasma membrane.

Genetic variability for Al resistance in maize has been reported (Jorge \& Arruda, 1997; Pintro et al., 1996 and Al-resistant maize cultivars have been selected for acidic soils (Pandey \& Gardner, 1992). Maize grain-yield increase has been obtained on acid soils through selection for tolerant cultivars in tropical maize populations. Most breeding work designed at increasing productivity on acid soil, focused on tolerance to Al toxicity (Garvin \& Carver, 2003).

$\mathrm{Al}$ resistance mechanisms can be grouped into two categories, exclusion of $\mathrm{Al}$ from the roots, and detoxification of $\mathrm{Al}$ ions in the plant (Taylor, 1991; Heim et al., 1999; Kochian et al., 2005; Zhou et al., 2007). Exclusion mechanisms include binding of $\mathrm{Al}$ in the cell wall, a plant-induced rhizosphere $\mathrm{pH}$ barrier, and root exudation of Al-chelating compounds. Organic acids have been reported to play a role both in $\mathrm{Al}$ exclusion, via release from the root and $\mathrm{Al}$ detoxification in the symplasm, where organic acids such as citric acid and malic acid could chelate $\mathrm{Al}$ and reduce or prevent its toxic effects at the cellular level, in particular protecting enzyme activity internally in the plant from the deleterious effect of $\mathrm{Al}$ (Delhaize et al., 1993). Genetic adaptation of plants to Al toxicity may provide a sustainable strategy to increase crop yield in the tropics at relatively low costs and low environmental impacts. This approach is particularly interesting for maize, where Al tolerant germplasm is available for selection and for genetic studies. A number of studies have been carried out to elucidate the genetic control of Al tolerance in maize, resulting in controversial results. However, a consensus among the authors has shown that the trait is quantitatively inherited under the control of few genes (Lima et al., 1995). Most of the genetics studies on aluminum tolerance in maize have evaluated the seminal root growth under nutrient solution as screening 
technique. Nutrient solutions with high concentration of aluminum have proven to be an effective way to discriminate tolerant and susceptible maize genotypes (Martins et al., 1999; Cancado et al., 1999). Although a large number of studies have been conducted, the genetic basis and the molecular mechanisms responsible for the genetic variability in maize $\mathrm{Al}$ tolerance are still poorly understood.

\subsection{Al toxicity and root growth}

High Al concentrations are particularly difficult to interpret in terms of physiological responses. A high proportion of $\mathrm{Al}$ in the nutrient growth medium might become inert by precipitation (e.g., with phosphate) or by polymerisation and complexation. Thus, the concentration of free $\mathrm{Al}$ promoting toxicity in plant metabolism can be much lower than that existing in the growth medium (Mengel \& Kirkby, 1987). Low concentrations of Al can also lead to a stimulation of root growth in tolerant genotypes of Zea mays L.

In non-accumulators plant species the negative effects of $\mathrm{Al}$ on plant growth prevail in soils with low $\mathrm{pH}$ (Marschner, 1995), the reduction in root growth being the most serious consequence (Tabuchi \& Matsumoto, 2001). This symptom of Al toxicity has been related to the linkage of Al to carboxylic groups of pectins in root cells (Klimashevsky \& Dedov, 1975) or to the switching of cellulose synthesis into callose accumulation (Teraoka et al., 2002), to Al inhibition of mitosis in the root apex (Rengel, 1992; Delhaize \& Ryan, 1995) implicating blockage of DNA synthesis, aberration of chromosomal morphology and structure occurrence of anaphase bridges and chromosome stickness and to Al-induced programmed cell death in the root-tip triggered by reactive oxygen species (Pan et al., 2001).

According to Comin et al. (1997) tolerant cultivars of Zea mays L. have different toxicity mechanisms, following monomeric or polymeric forms of Al supplied to the growth medium. Aluminum can easily polymerise, transforming the monomeric form $\left(\mathrm{Al}^{3+}\right)$ into a polymeric form $\left(\mathrm{Al}_{13}\right)$, which is much more phytotoxic in maize. Yet, although Bashir et al. (1996) had noticed Al nucleotypic effects on maize, a lack of nuclear DNA content variability was found among wheat isolines differing in $\mathrm{Al}$ response as well as four genes that ameliorate $\mathrm{Al}$ toxicity (Ezaki et al., 2001). Indeed, the general responses to Al excess by tolerant genotypes deal with the varying ability of plants to modify the $\mathrm{pH}$ of the soil-root interface (Mengel \& Kirkby, 1987; El-Shatnawi \& Makhadmeh, 2001).

\section{Conclusion}

Soil acidity and aluminium toxicity is certain one of the most damaging soil conditions which affecting the growth of most crops. In this paper soil $\mathrm{pH}$, exchangeable acidity and mobile aluminium (Al) status in profiles of pseudogley soils of Western Serbia region were studied. Total 102 soil profiles were opened during 2008 in the Western Serbia. The tests encompassed 54 field, 28 meadow, and 20 forest profiles. From the opened profiles, samples of soil in the disturbed state were taken from the humus and Eg horizons (102 profiles); then from the $B_{1}$ tg horizon of 39 fields, 24 meadows and 15 forest profiles (total 78) and from the $\mathrm{B}_{2} \operatorname{tg}$ horizon of 14 fields, 11 meadows, and 4 forest profiles (total 29). Laboratory determination of exchangeable acidity was conducted in a suspension of soil with a $1.0 \mathrm{M}$ 
$\mathrm{KCl}$ solution ( $\mathrm{pH}$ 6.0) using a potentiometer with a glass electrode, as well as by Sokolov's method, where the content of $\mathrm{Al}$ ions in the extract is determined in addition to total exchangeable acidity $\left(\mathrm{H}^{+}+\mathrm{Al}^{3+}\right.$ ions). Mean $\mathrm{pH}(1 \mathrm{M} \mathrm{KCl})$ of tested soil profiles were 4.28, 3.90 and 3.80, for $\mathrm{Ah}, \mathrm{Eg}$ and $\mathrm{B}_{1}$ tg horizons, respectively. Also, soil $\mathrm{pH}$ of forest profiles was lower in comparison with meadows and arable lands (means: 4.06, 3.97 and 3.85, for arable lands, meadows and forest, respectively). Soil acidification is especially intensive in deeper horizons because $27 \%(\mathrm{Ah}), 77 \%(\mathrm{Eg})$ and $87 \%\left(\mathrm{~B}_{1} \mathrm{tg}\right)$ soil profiles have $\mathrm{pH}$ lower than 4.0 . Mean total exchangeable acidity (TEA) of tested soil profiles were 1.55, 2.33 and 3.40 meq $100 \mathrm{~g}^{-1}$, for $\mathrm{Ah}, \mathrm{Eg}$ and $\mathrm{B}_{1} \operatorname{tg}$ horizons, respectively. However, it is considerably higher in forest soils (mean 3.39 meq 100 $\mathrm{g}^{-1}$ ) than in arable soils and meadows (means 1.96 and 1.93, respectively). Mean mobile $\mathrm{Al}$ contents of tested soil profiles were 11.02, 19.58 and $28.33 \mathrm{mg}$ $\mathrm{Al} 100 \mathrm{~g}^{-1}$, for $\mathrm{Ah}, \mathrm{Eg}$ and $\mathrm{B}_{1} \operatorname{tg}$ horizons, respectively. Soil $\mathrm{pH}$ and TEA in forest soils are considerably higher (mean 26.08 meq Al 100g-1) than in arable soils and meadows (means 16.85 and $16.00 \mathrm{Al} 100 \mathrm{~g}^{-1}$, respectively). The Eg and $\mathrm{B}_{1}$ tg horizons of forest soil profiles have especially high mobile Al contents (means 28.50 and $32.95 \mathrm{mg}$ Al $100 \mathrm{~g}$-1 , respectively). Frequency of high levels of mobile $\mathrm{Al}$ is especially high in forest soils because $35 \%$ (Ah), 85.0 $\%(\mathrm{Eg})$ and $93.3 \%\left(\mathrm{~B}_{1} \mathrm{tg}\right)$ of tested profiles were in range above $10 \mathrm{mg} \mathrm{Al} 100 \mathrm{~g}^{-1}$.

$\mathrm{Al}$ ions translocate very slowly to the upper parts of plants. Most plants contain no more than $0.2 \mathrm{mg} \mathrm{Al} \mathrm{g}^{-1}$ dry mass. However, some plants, known as $\mathrm{Al}$ accumulators, may contain over 10 times more $\mathrm{Al}$ without any injury. Tea plants are typical $\mathrm{Al}$ accumulators: the $\mathrm{Al}$ content in these plants can reach as high as $30 \mathrm{mg} \mathrm{g}^{-1}$ dry mass in old leaves. Approximately 400 species of terrestrial plants, belonging to 45 families, have so far been identified as hyperaccumulators of various toxic metals.

The main aluminum toxicity symptom is inhibition of root elongation with simultaneous induction of glucan ( $\beta-1,3$-callose) synthesis, which is apparent alter even a short exposure time. Aluminium causes extensive root injury, leading to poor ion and water uptake. Aluminum is known to induce a decrease in mitotic activity in many plants, and the aluminum-induced reduction in the number of proliferating cells is accompanied by the shortening of the region of cell division in maize.

Genetic adaptation of plants to $\mathrm{Al}$ toxicity may provide a sustainable strategy to increase crop yield in the tropics at relatively low costs and low environmental impacts. This approach is particularly interesting for maize, where Al tolerant germplasm is available for selection and for genetic studies.

High Al concentrations are particularly difficult to interpret in terms of physiological responses. A high proportion of $\mathrm{Al}$ in the nutrient growth medium might become inert by precipitation (e.g., with phosphate) or by polymerisation and complexation. Thus, the concentration of free $\mathrm{Al}$ promoting toxicity in plant metabolism can be much lower than that existing in the growth medium.

\section{Acknowledgment}

This research was supported by a grant from the Ministry of Science of the Republic of Serbia (Projects TR 31073 III 41011 and ON 171021) 


\section{References}

Baker, A. J. M.; McGrath, S. P.; Reeves, R. D. \& Smith, J. A. C. (2000). Metal hyperaccumulator plants: A review of the ecology and physiology of a biological resource for phytoremediation of metal-polluted soils. In: Phytoremediation of Contaminated Soil and Water. N. Terry \& G. Banuelos (Eds.), 85-107, Lewis Publisher, Boca Raton

Barcelo, J. \& Poschenrieder, C. (2002). Fast root growth responses, root exudates and internal detoxification as clues to the mechanisms of aluminium toxicity and resistance: A review. Env. Exp. Bot., 48, 75-92

Bashir, A.; Biradar, D.P.\& Rayburn, A.L. (2006). Determining relative abundance of specific DNA sequences in flow cytometrically sorted maize nuclei. J. Exper. Botany, 46, 451457

Blancaflor, E. B.; Jones, D. L. \& Gilroy S. (1998). Alterations in the cytoskeleton accompany aluminum-induced growth inhibition and morphological changes in primary roots of maize. Plant Physiol., 118, 159-172

Ciamporová, M. (2002). Morphological and structure responces of plant roots to aluminium at organ, tissue, and cellular levels. Biol. Pl., 45, 161-171

Cançado, G. M. A.; Loguercio, L. L.; Martins, P. R.; Parentoni, S. N.; Borém, A.; Paiva, E. \& Lopes, M. A. (1999). Hematoxylin staining as a phenotypic index for aluminum tolerance selection in tropical maize (Zea mays L.). Theor. Appl. Genet., 99, 747-754

Comin-Chiaramonti, P.; Cundari, A.; Piccirillo, E.M.; Gomes, C.B.; Castorina, F.; Censi , P.; Demin A.; Marzoli, A.; Speziale, S. \& Velázquez, V.F. (1997). Potassic and sodic igneous rocks from Eastern Paraguay: their origin from the lithospheric mantle and genetic relationships with the associated Paraná flood tholeiites. J. Petrology, 38, 495-528

Delhaize, E.; Craig, S.; Beaton, C. D,.; Bennet, R. J.; Jagadish, V. C. \& Randall, P. J. (1993). Aluminum tolerance in wheat (Triticum aestivum L.) I. Uptake and distribution of aluminum in root apices. Plant Physiol., 103, 685-693

Delhaize, E. \& Ryan, P. R. (1995). Aluminium toxicity and tolerance in plants. Plant Physiol., 107, 315-321

Dugalic, G.; Krstic, D.; Jelic, M.; Nikezic, D.; Milenkovic, B.; Pucarevic, M. \& ZeremskiSkoric, T. (2004). Heavy metals, organics and radioactivity in soil of western Serbia . J. Hazard. Mat., 177, 697-702

El-Shatnawi, M. K. \& Makhadmeh, I. M. (2001). A Review- Ecophysiology of the plantrhizosphere system. J. Agronomy \& Crop Science, 187, 1-9

Ezaki, B.; Katsuhara, M.; Kawamura, M. \& Matsumoto, H. (2001). Different mechanisms of four aluminium (Al)-resistant transgenes for $\mathrm{Al}$ toxicity in Arabidopsis. Plant Physiol., 127, 918-927

Foy, C. D. (1984). Physiological effects of hydrogen, Al and manganese toxicities in acid soil. In: Soil acidity and liming. F. Adams, (Ed.), 57-97, American Society of Agronomy, Madison, Wisconsin

Garvin, D. F. \& Carver B. F. (2003), The Role of the Genotype in Tolerance to Acidity and Aluminium Toxicity. In: Handbook of Soil Acidity. Z. Rengel (Ed.), 387-406, Marcel Dekker, New York 
Grabski, S.; Arnoys, E.; Busch, B. \& Schindler, M. (1998). Regulation of actin tension in plant cells by kinases and phosphatases. Plant Physiol., 116, 279-290

Heim, A.; Luster, J.; Brunner, I.; Frey, B. \& Frossard, E. (1999). Effects of aluminium treatment on Norway spruce roots: aluminium bindings forms, element distribution, and release of organic substances. Plant and Soil, 216, 103-116

Horst, W. J.; Püschel, A. K. \& Schmohl, N. (1997). Induction of callose formation is a sensitive marker for genotypic aluminium sensitivity in maize. Plant Soil, 192, 23-30

Jakovljevic, M.; Pantovic, M. \& Blagojevic, S. (1995). Laboratory Manual of Soil and Water Chemistry (in Serbian), Faculty of Agriculture, Belgrade

Jelic, M.; Djalovic, I.; Milivojevic, J. \& Krstic, D. (2010). Mobile aluminium content of vertisols as dependent upon fertilization system and small grains genotypes, Proceedings of 3nd International Scientific/Professional Conference Agriculture in Nature and Environment Protection, pp. 137-142, ISBN 978-953-7693-008, Vukovar, Croatia, May 31- June 2, 2010

Jones, D. L.; Blancaflor, E. B.; Kochian, L. V. \& Gilroy S. (2006). Spatial coordination of aluminium uptake, production of reactive oxygen species, callose production and wall rigidification in maize roots. Plant Cell Environ., 29, 1309-1318

Jorge, R. A. \& Arruda, P. (1997). Aluminum-induced organic acid exudation by roots of aluminum-tolerant tropical maize. Phytochemistry, 45, 675-681

Jovanovic,., Z.; Djalovic, I.; Komljenovic, I.; Kovacevic, V. \& Cvijovic, M. (2006). Influences of liming on vertisol properties and yields of the field crops. Cereal Res. Commun., 34, 517-520

Jovanovic, Z.; Djalovic, I.; Tolimir, M. \& Cvijovic, M. (2007). Influence of growing sistem and NPK fertilization on maize yield on pseudogley of Central Serbia. Cereal Res. Commun., 35, 1325-1329

Kidd, P. S. \& Proctor, J. (2001). Why plants grow poorly on very acid soils: are ecologists missing the obvious? J. Exp. Bot., 52, 791-799

Kinraide, T. B. (1991). Identity of rhizotoxic aluminium species. Plant Soil, 134, 167-178 Kochian, K. V. (1995). Cellular mechanisms of aluminium toxicity and resistance in plant. Annu. Rev. Plant Physiol. Mol. Biol., 46, 237-260

Klimashevskii, E. L. \& Dedov, V. M. (1975). Localization of growth inhibiting action of aluminium ions in alongating cell walls. Fiziologiia Rastenii, 22, 1183-1190

Kochian, K. V. (1995). Cellular mechanisms of aluminium toxicity and resistance in plant. Annu. Rev. Plant Physiol. Mol. Biol., 46, 237-260

Kochian, L. V.; Piñeros, M. A. \& Hoekenga O. A. (2005). The physiology, genetics and molecular biology of plant aluminum resistance and toxicity. Plant and Soil, 274, 175-195

Krstic, D.; Nikezic, D.; Stevanovic, N. \& Jelic, M. (2004). Vertical profile of ${ }^{137 C s}$ in soil. Appl. Radiat. Issotopes, 61, 1487-1492

Krstic, D.; Stevanovic, N.; Milivojevic, J. \& Nikezic, D. (2007). Determination of the soil-tograss transfer of ${ }^{137} \mathrm{Cs}$ and its relation to several soil properties at various locations in Serbia. Isotopes Environ. Health St., 43, 65-73

Lima, M.; Miranda, Filho, J. B. \& Furlani, P. R. (1995). Diallel cross among inbred lines of maize differing in aluminum tolerance. Braz. J. Genet., 4, 579-584 
Ma, Q.; Hiradate, J. F.; Nomoto, K.; Iwashita, T. \& Matsumoto, H. (1997). Internal detoxification mechanism of $\mathrm{Al}$ in hydrangea: Identification of $\mathrm{Al}$ form in the leaves. Plant Physiol., 113, 1033-1039

Marschner, H. (1995). Mineral nutrition of higher plants (2nd ed.), Academic Press, London

Martins, P. R.; Parentoni, S. N.; Lopes, M. A. \& Paiva, E. (1999). Eficiĕncia de indices fenotǐpicos de comprimento de raiz seminal na avaliaçăo de plantas individuais de milho quanto ă tolerăncia ao aluminio. Pesquisa Agropecuăria Brasileira, 34, 18971904

Matsumoto, H.; Hirasawa, E.; Torikai, H. \& Takahashi, E. (1976). Localization of absorbed aluminum in pea root and its binding to nucleic acids. Plant Cell. Physiol., 17, 127-137

Mengel, K. \& Kirkby, E.A. (1987). Principles of Plant Nutrition (4th ed.), International Potash Institute, IPI, Bern, Switzerland, pp. 685.

Milivojevic, J.; Nikezic, D.; Krstic, D.; Jelic, M. \& Djalovic, I. (2011). Influence of PhysicalChemical Characteristics of Soil on Zinc Distribution and Availability for Plants in Vertisols of Serbia. Pol. J. Environ. Stud., 20, 993-1000

Pan, J. M.; Zhu, M. \& Chen, H. (2001). Aluminium-induced cell death in root tip cells of barley. Environm. Exp. Bot., 46, 71-79

Panda, S. K. \& Matsumoto, H. (2007). Molecular physiology of aluminium toxicity and tolerance in plants. The Botanical Revew, 73, 326-347

Pandey, S. \& Gardner, C. O. (1992). Recurrent selection for population, variety and hybrid improvement in tropical maize. Adv. Agron., 48, 1-87

Parker, D. R. \& Bertsch, E. M. (1992). Formation of the " $\mathrm{Al}_{13}$ " tridecameric polycation under diverse synthesis conditions. Environm. Sci. Technol., 26, 914-921

Pintro, J.; Barloy, J. \& Fallavier, P. (1996). Aluminium effects on the growth and mineral composition of corn plants cultivated in nutrient solution at low aluminum activity. J. Plant Nutr., 19, 729-741

Rengel, Z. (1992). Role of calcium in aluminium toxicity. New Phytol., 121, 499-513

Rengel, Z. (2004). Aluminium cycling in the soil-plant-animal-human continuum. Biometals, $17,669-689$

Samac, D. A. \& Tesfaye, M. (2003). Plant improvement for tolerance to aluminium in acid soils. Plant Cell, Tissue and Organ Culture, 75, 189-207

Sivaguru, M. \& Horst, W. J. (1998). Differential impacts of aluminum on microtubule organization depend on growth phase in suspension-cultured tobacco cells. Physiol. Plant, 107, 110-119

Tabuchi, H. \& Matsumoto, H. (2001). Changes in cell wall properties on wheat (Triticum aestivum) roots during aluminium-induced growth inhibition. Physiol. Plant, 112, 353-358

Takabatake, R. \& Shimmen, T. (1997). Inhibition of electrogenesis by aluminum in characean cells. Plant Cell Physiol., 38, 1264-1271

Taylor, G. J. (1991). Current views of the aluminum stress response: the physiological basis of tolerance. Curr Top Plant Biochem Physiol., 10, 57-93

Teraoka, T.; Kaneko, M.; Mori, S. \& Yoshimura, E. (2002). Aluminium rapidly inhibits cellulose synthesis in roots of barley and wheat seedings. J. Plant Physiol., 123, 987-996 
von Uexküll, H. R. \& Mutert, E. (1995). Global extent, development and economic impact of acid soils. Plant Soil, 171, 1-15

Zhou L. L., Bai G. H., Carver B., Zhang D. D. (2007): Identification of new sources of aluminum resistance in wheat. Plant Soil, 297: 105-118 


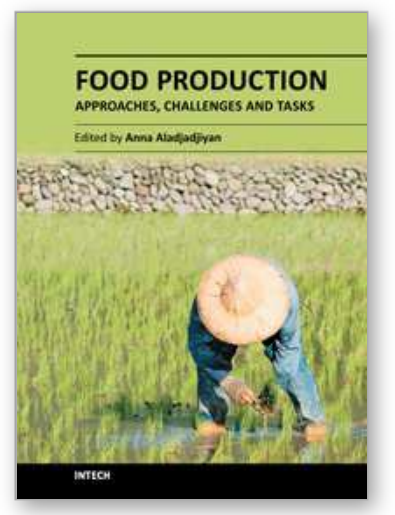

\author{
Food Production - Approaches, Challenges and Tasks \\ Edited by Prof. Anna Aladjadjiyan
}

ISBN 978-953-307-887-8

Hard cover, 270 pages

Publisher InTech

Published online 20, January, 2012

Published in print edition January, 2012

This book is devoted to food production and the problems associated with the satisfaction of food needs in different parts of the world. The emerging food crisis calls for development of sustainable food production, and the quality and safety of the food produced should be guaranteed. The book contains thirteen chapters and is divided into two sections. The first section is related to social issues rising from food insufficiency in the third world countries, and is titled "Sustainable food production: Case studies". The case studies of semi-arid Africa, Caribbean and Jamaica, Burkina Faso, Nigeria, Pacific Islands, Mexico and Brazil are discussed. The second section, titled "Scientific Methods for Improving Food Quality and Safety", covers the methods for control and avoidance of food contaminants. Substitution of chemical treatment with physical, rapid analytical methods for control of contaminants, problems in animal husbandry related to diary production and hormones in food producing animals, approaches and tasks in maize and rice production are in the covered by 6 chapters in this section.

\title{
How to reference
}

In order to correctly reference this scholarly work, feel free to copy and paste the following:

Dragana Krstic, Ivica Djalovic, Dragoslav Nikezic and Dragana Bjelic (2012). Aluminium in Acid Soils: Chemistry, Toxicity and Impact on Maize Plants, Food Production - Approaches, Challenges and Tasks, Prof. Anna Aladjadjiyan (Ed.), ISBN: 978-953-307-887-8, InTech, Available from:

http://www.intechopen.com/books/food-production-approaches-challenges-and-tasks/aluminium-in-acid-soilschemistry-toxicity-and-impact-on-maize-plants

\section{INTECH}

open science | open minds

\author{
InTech Europe \\ University Campus STeP Ri \\ Slavka Krautzeka 83/A \\ 51000 Rijeka, Croatia \\ Phone: +385 (51) 770447 \\ Fax: +385 (51) 686166 \\ www.intechopen.com
}

\author{
InTech China \\ Unit 405, Office Block, Hotel Equatorial Shanghai \\ No.65, Yan An Road (West), Shanghai, 200040, China \\ 中国上海市延安西路65号上海国际贵都大饭店办公楼 405 单元 \\ Phone: +86-21-62489820 \\ Fax: +86-21-62489821
}


(C) 2012 The Author(s). Licensee IntechOpen. This is an open access article distributed under the terms of the Creative Commons Attribution 3.0 License, which permits unrestricted use, distribution, and reproduction in any medium, provided the original work is properly cited. 